TITLE:

\title{
Appetite-enhancing Effects of trans -Cinnamaldehyde, Benzylacetone and 1-Phenyl-2-butanone by Inhalation
}

\author{
$\operatorname{AUTHOR}(S)$ :
}

Ogawa, Kakuyou; Ito, Michiho

\section{CITATION:}

Ogawa, Kakuyou ...[et al]. Appetite-enhancing Effects of trans -Cinnamaldehyde,

Benzylacetone and 1-Phenyl-2-butanone by Inhalation. Planta Medica 2016, 82: 84-88

ISSUE DATE:

2016-01

URL:

http://hdl.handle.net/2433/244238

\section{RIGHT:}

この論文は出版社版でありません。引用の際には出版社版をご確認ご 利用ください。; This is not the published version. Please cite only the published version.; 許諾条件に基づいて掲載しています。 


\title{
Appetite-enhancing effects of trans-cinnamaldehyde, benzylacetone and 1-phenyl-2-butanone by inhalation
}

Kakuyou Ogawa, Michiho Ito

\section{Affiliation}

Department of Pharmacognosy, Graduate School of Pharmaceutical Sciences, Kyoto University; 46-29 Yoshidashimoadachi-cho, Sakyo-ku, Kyoto 606-8501, Japan

\section{Correspondence}

Professor Michiho Ito, PhD, Department of Pharmacognosy, Graduate School of Pharmaceutical Sciences, Kyoto University; 46-29 Yoshidashimoadachi-cho, Sakyo-ku, Kyoto 606-8501, Japan. E-mail: michihoi@pharm.kyoto-u.ac.jp

\begin{abstract}
Fragrance in the air and odours of foods and drinks are reported to affect feeding behaviours in humans and other animals. Many previous studies focusing on the relationship between fragrance and appetite have described a reduction in food intake by fragrance administration to help in the prevention of lifestyle diseases. Aromatic herbal medicines, such as cinnamon bark and fennel fruit, are considered to have appetite-enhancing effects, and they are often blended in stomachics for relief of asitia and gastric distress in Japan. These fragrant herbal medicines contain many essential oils and their fragrances are hypothesised to be active substances. In this study, food intake and expression of neuropeptide $\mathrm{Y}$ and pro-opiomelanocortin in the hypothalamus were investigated in mice after inhalation of fragrant compounds or essential oils. Food intake was increased 1.2-fold and neuropeptide $\mathrm{Y}$ mRNA expression in the hypothalamus was increased significantly in mice after inhalation of trans-cinnamaldehyde, benzylacetone or 1-phenyl-2-butanone compared with the control group. These compounds might be effective for treating loss of appetite (anorexia) or eating disorders in elderly and infirm people via a non-invasive route of administration, namely, inhalation.
\end{abstract}

\section{Abbreviations}

NPY: neuropeptide Y

POMC: pro-opiomelanocortin 


\section{Key words}

trans-Cinnamaldehyde, Benzylacetone, 1-Phenyl-2-butanone, Appetite enhancement, Inhalation, Neuropeptide Y

\section{Introduction}

Some compounds extracted from several plants have recently shown effects on feeding behaviour, and studies on these compounds have since been conducted to examine whether these compounds can contribute to the prevention of lifestyle diseases [1,2,3]. As one example, geranium essential oil administered via inhalation, but not via oral administration, was found to reduce food intake in rats. These studies investigated the expression levels in the hypothalamus of pro-opiomelanocortin (POMC) and neuropeptide Y (NPY), which are involved in the mechanisms of feeding behaviour. Some of the studies revealed that certain compounds and essential oils significantly increased mRNA expression of POMC, which has been linked with a decrease in food intake [1,3], while other studies demonstrated some compounds and essential oils lowered mRNA expression of NPY, which is believed to increase food intake [2,3].

Apart from efforts to reduce food intake in healthy people, there is a need to prevent diseases caused mainly by malnutrition in many elderly and infirm people. A non-invasive method of improving appetite would be beneficial for improving their quality of life and primary care [4].

In Japan, over-the-counter medicines administered orally to treat loss of appetite (anorexia) often contain herbal aromatic stomachics such as the bark of Cinnamomum cassia Blume (Lauraceae) and the fruit of Foeniculum vulgare Miller (Umbelliferae). These fragrant herbal medicines contain many essential oils, and their fragrances are suggested to contribute to their appetite-enhancing effects [5].

In this study, food intake and expression of POMC and NPY mRNA in the hypothalamus after inhalation of fragrances from trans-cinnamaldehyde (a main component of C. cassia essential oil) [6], benzylacetone (a compound contained in the smoke of heated agarwood) [7] and their analogues were analysed in mice.

Figure 1

\section{Results}

The amount of food intake was significantly increased in fasted mice administered trans-cinnamaldehyde, benzylacetone or 1-phenyl-2-butanone compared with animals in the control group. The amount of food consumed by the mice administered 
trans-cinnamaldehyde and benzylacetone were approximately 1.2-fold higher than that of the control group (Fig. 2). Ghrelin, the positive control compound, significantly increased food intake in mice compared with the vehicle; however, food intake was increased in mice administered trans-cinnamaldehyde, benzylacetone or 1-phenyl-2-butanone by 1.07-, 1.09- and 1.06-fold compared with ghrelin, respectively.

Figure 2

Table 1

The expression levels of NPY and POMC mRNAs in unfasted mice hypothalamus after inhalation of the fragrances are shown in Fig. 3. The mRNA expression of NPY was significantly elevated in the same groups of mice that showed higher food intake compared with controls in Fig. 2, whereas the expression of POMC appeared to be unrelated to the change in food intake. However, the amount of food intake was about 1.2-fold higher in unfasted mice administered trans-cinnamaldehyde or benzylacetone compared with the unfasted mice in the control group (Fig. 3), although due to dispersion of data, this relationship was not significant. Here, the ratio of increase was similar in fasted and unfasted mice.

Figure 3

Table 2

\section{Discussion}

Among the fragrant compounds examined in this study, those harbouring a phenylpropanoid structure showed positive effects on appetite enhancement in mice, whereas such effects were not observed in compounds that either did not have carbonyl groups or did have these groups but in the adjacent position to the phenyl group. In other studies, similar structure-activity relationships for carbonyl groups and the length of aliphatic chains have been reported [8,9]. Furthermore, $(R)$-linalool and geranium essential oil, which are rich in monoterpene compounds such as geraniol and citronellol (Table 1S, Supporting Information), did not show effects on appetite enhancement. The putative mechanisms of any effects induced by fragrant compounds administered via inhalation include two pathways: (i) the stimulation of receptors in the central nervous system by compounds being absorbed and transferred to blood and (ii) the 
direct stimulation of olfactory receptors [1,10,11,12]. In some studies it was demonstrated that the effects were abrogated by olfactory impairment $[1,11]$. To clarify the mechanisms of action of the appetite-enhancing effects, benzylacetone was dissolved and diluted in corn oil (Wako Pure Chemical Industries, Ltd., Osaka, Japan) and administered intraperitoneally $(1.0,0.1,0.01 \mu \mathrm{g} / \mathrm{kg})$ to mice. However, significant effects were not observed in any group (Fig. 4.) This finding suggests that the appetite-enhancing effects might not be caused by the compound transferred to the blood stream, but instead by direct olfactory stimulation.

Figure 4

The results shown in Figures 2 and 3 indicate that the enhancement of food intake seemed to be positively correlated with the changes in NPY mRNA expression. Comparing Figures 2 and 3 indicated that the appetite-enhancing effects were similar whether the mice were fasted or not; therefore, comparing Figures 2 and 3 was considered to be appropriate. This could imply that NPY mRNA expression was significantly increased by administration of trans-cinnamaldehyde, benzylacetone or 1-phenyl-2-butanone via inhalation, and indeed hypothalamic NPY is known as a peptide that stimulates food intake [13]. It was previously reported that the expression of NPY decreased as that of POMC increased and food intake decreased [3]. However, the present results do not concur; the expression of NPY significantly increased when food intake also increased and the expression of POMC decreased at the same time, albeit not significantly, when food intake increased. The expression levels of NPY and POMC did not significantly contradict the results of previously studies when fragrant compounds were administered by inhalation, although the expression level of POMC tended to decrease. The putative mechanism of appetite-enhancing effect and the relation between food intake and mRNA expression in the hypothalamus suggest that the appetite-enhancing could be caused by stimulation of the olfactory receptor followed by an increase in NPY and stimulation of the NPY receptor.

Compounds such as $\Delta$-tetrahydrocannabinol, diazepam [14], anandamide [15], morphine [16], and ghrelin [17] were previously reported to have appetite-enhancing effects. Of note, $\Delta 9$-tetrahydrocannabinol, diazepam and morphine have addictive properties; therefore, regulation of these compounds is very strict. Thus, repetitive or continuous use of these compounds for anorexia would be problematic [18-21]. Ghrelin could be administered via injection, although it has stability problems during long-term storage and is unstable even if kept at low temperature with stabilizing agents and 
protease inhibitors [22]. Compared with these compounds, trans-cinnamaldehyde, benzylacetone and 1-phenyl-2-butanone are unique in that they could be administered non-invasively via inhalation, and are expected to improve anorexia or eating disturbances of elderly and infirm individuals.

Recently, it was reported that a Kampo medicine, rikkunshito, increased plasma ghrelin levels in rats administered cisplatin and promoted recovery from anorexia [23]. Other experiment showed that ghrelin increased the expression of NPY mRNA in the hypothalamus of rats [24]. Because both benzylacetone and ghrelin increase the expression of NPY mRNA in the hypothalamus, benzylacetone could be used for conditions similar to those treated with rikkunshito.

In conclusion, trans-cinnamaldehyde, benzylacetone and 1-phenyl-2-butanone displayed appetite-enhancing effects via inhalation at doses of $4.5 \times 10^{-4} \mathrm{mg} / \mathrm{cage}$. The common features of these active compounds are the presence of both carbonyl and phenyl groups in non-adjacent positions. mRNA expression of NPY in the hypothalamus of mice was increased when these compounds were administered via inhalation. However, appetite-enhancing effects were not observed when the mice were administered benzylacetone intraperitoneally. These results indicate that the stimulation of olfactory receptors on nasal mucosa by inhaled compounds may increase the mRNA expression of NPY in the hypothalamus, leading to the enhancement of food intake. Comparing the results of this study with those reported by Choi et al. [1], it is interesting that both benzylacetone and geranium essential oil showed their effects by stimulating olfactory receptors, even though they produced opposite effects.

To our knowledge, there have been only three reported studies of the effects of fragrant compounds on food intake [1,3,25], all showing a reduction in food intake.

The doses in the reported studies were significantly higher than in our study. For example, the amount of geranium oil used in Choi et al.'s study [1] was estimated to be $20 \mu \mathrm{L} /$ cage $\left(6.4 \times 10^{-4} \mu \mathrm{L} / \mathrm{cm}^{3}\right)$, which is much higher than the dose of $4.5 \times 10^{-3}$ $\mathrm{mg} /$ cage $\left(7.6 \times 10^{-8} \mathrm{mg} / \mathrm{cm}^{3}\right)$ used here. The high dose of the oils could increase the expression level of POMC mRNA [1,3], which may increase the levels of $\alpha$-melanocyte stimulating hormone formed by metabolism of POMC. $\alpha$-Melanocyte stimulating hormone reduces the appetite-enhancing effects of NPY [13]; therefore, both the decrease in food intake caused by higher doses and the appetite-enhancing effect of lower doses can be explained.

The three compounds investigated in this study have characteristics of food intake enhancement: they have a pleasant smell, are chemically stable and are easy to synthesise, and therefore might be good candidates for functional fragrances that might 
attract people to foods with these flavours. Herbal medicines or spices containing phenylpropanoid compounds, including cinnamon, were used to treat anorexia [26], and it was suggested that the component compounds of these spice essential oils [5], such as trans-anethole, stimulated olfactory receptors different from the ones stimulated by trans-cinnamaldehyde [27]. This suggests that some compounds that have structural features different from trans-cinnamaldehyde or benzylacetone might enhance appetite via inhalation. Accordingly, the appetite-enhancing effects of other phenylpropanoid compounds contained in spices and herbal medicines should be clarified in humans in addition to animals.

\section{Materials and Methods}

Materials Essential oils and compounds used in this study (Fig. 1) were obtained as follows. trans-Cinnamaldehyde and benzaldehyde were purchased from Nacalai Tesque, benzylacetone, 1-phenyl-2-butanone, butylbenzene and 6-methy-5-hepten-2-one were purchased from Tokyo Chemical Industry. Geranium essential oil was purchased from Tisserand and (R)-linalool was obtained from Sigma-Aldrich. All fragrant compounds used in this study were of the highest grade available. Triethyl citrate was purchased from Merck KGaA, and 2-mercaptoethanol and ethanol were from Nacalai Tesque. Ghrelin (rat) was purchased from Peptide Institute Inc.

Animals The animal studies were designed according to the recommendations of the Animal Research Committee of Kyoto University, Kyoto, Japan (authorisation numbers: 2014-17). Four-week-old male ddY mice (approximately $16 \mathrm{~g}$ at the time of purchase) were from Japan SLC. The mice were housed in colony cages (six mice per cage) at an ambient temperature of $25 \pm 2{ }^{\circ} \mathrm{C}$ under a 12-h light-dark cycle. The mice used for the measurement of gene expression in the hypothalamus (25 $\mathrm{g}$ at the time of experiments) were fed standard pellet chow and water ad libitum. The mice used in the feeding tests (19 $\mathrm{g}$ at the time of the experiments) were fasted for up to but not more than $24 \mathrm{~h}$ before starting the tests, but water was available ad libitum. All studies were conducted from 08:00 to 17:00.

Feeding test Feeding tests were performed according to the previous studies of Choi et al. (2011) and Miyoshi et al. (2013) [1,8]. Fragrant compounds and essential oils were dissolved in and diluted with triethyl citrate $(400 \mu \mathrm{L})$ and dropped onto four filter paper discs attached to the four corners of the glass cage $(30 \mathrm{~cm} \times 60 \mathrm{~cm} \times 34 \mathrm{~cm} ; 61.2 \mathrm{~L}$ ). The cage was filled with vaporised solution by diffusion for $60 \mathrm{~min}$. The fasted mice 
inhaled fragrances in the cage for $1 \mathrm{~h}$ before the end of the fast. At the end of fast, the mice were taken from the glass cage and placed in plastic cages and then given approximately $10 \mathrm{~g}$ of weighed standard pellet chow. After $4 \mathrm{~h}$ of feeding, they were removed from the plastic cages and the remaining pellets were weighed to calculate food intake. The control group inhaled air after placement of triethyl citrate in the cage. Ghrelin (rat), a hormone that has an appetite-enhancing effect, was dissolved in saline (Otsuka Pharmaceutical) and injected intraperitoneally (158 nmol/kg) [28] as a positive control $1 \mathrm{~h}$ before starting the feeding test and saline was injected as a vehicle.

Evaluation of gene expression in mice hypothalamus The evaluation method for gene expression used in this study was modified from that described previously [1,10,29]. The mice that were not fasted inhaled the fragrance in their cage for $60 \mathrm{~min}$, and then their brains were removed after cervical dislocation and decapitation. Hypothalamus was isolated from the brain and was ground up using liquid nitrogen. Total RNA was extracted from the hypothalamus using RNeasy fibrous tissue mini kit (Qiagen). cDNA was synthesised using Revatra Ace (Toyobo) and oligo (dT) 15 primer (Takara Bio Inc.) with extracted total RNA as a template, and the resultant cDNA was refined by NucleoSpin Gel and PCR Clean-up (MACHEREY-NAGEL). Gene expression in the hypothalamus was measured using THUNDERBIRD ${ }^{\circledR} \mathrm{SYBR}^{\circledR}$ qPCR Mix (TOYOBO) on StepOnePlus ${ }^{\mathrm{TM}}$ (Applied Biosystems). Quantitative real-time PCR was performed with a temperature programme starting at $95.0^{\circ} \mathrm{C}$ for $20 \mathrm{~s}$, followed by 40 cycles of $95.0^{\circ} \mathrm{C}$ for $3 \mathrm{~s}, 45.0^{\circ} \mathrm{C}$ for $30 \mathrm{~s}$ and $72.0^{\circ} \mathrm{C}$ for $30 \mathrm{~s}$. The primers used in this study are shown in Table 1. Calibration curves for each couple of primers were plotted using the results of real-time PCR. The calibration curves of $\beta$-actin, POMC and NPY and their correlation coefficients are shown in Table 1. The linearity of the calibration curves was evaluated with the correlation coefficients, and the appropriate values were set to $>0.98$ [8]. The efficiency of target amplification was calculated based on the slopes of the calibration curves, and the efficiency was confirmed to be 0.8-1.2 [30]. Quantitative evaluation of gene expression was analysed using the $2^{-\Delta \Delta \mathrm{Ct}}$ method [31].

Statistical analysis Results are presented as the mean \pm standard error of the mean (S.E.M). Statistical analyses were performed by Dunnett's test and subsequent $t$-test with Bonferroni comparison for multiple comparisons [1,8] using GraphPad Instat (GraphPad Software) and R (R Development Core Team, R Foundation for Statistical Computing). A probability level of $p<0.05$ was considered statistically significant [8]. 
Supporting information Analysis result for geranium essential oil and method of GC-GC/MS analysis are available as Supporting Information.

\section{Conflict of Interest}

The authors declare no conflict of interest.

\section{References:}

1 Choi SJ, Ye SB, Na H.G, Kim GO, Bae CH, Song SY, Kim YW, Park SY, Kim YD. Effect of Geranium Essential Oil on Food Intake via Olfactory Stimulus. Korean J Otorhinolaryngol-Head Neck Surg 2011; 54: 766-770.

2 Hamao M, Matsuda H, Nakamura S, Nakashima S, Semura S, Maekubo S, Wakasugi S, Yoshikawa M. Anti-obesity effects of the methanolic extract and chakasaponins from the flower buds of Camellia sinensis in mice. Bioorg Med Chem 2011; 19: 6033-6041.

3 Yamamoto T, Inui T, Tsuji T. The odor of Osmanthus fragrans attenuates food intake. Sci Rep 2013; 3.

4 Kuzuya M. Nutritional assessment and nutritional management for the elderly. Nippon Ronen Igakkai Zasshi 2003; 40: 199-203.

5 Kariyone T. Saishin Shouyakugaku, $6^{\text {th }}$ ed. Tokyo, Japan: Hirokawa Publishing; 1988: 433-434.

6 Dong $Y, \mathrm{Lu} N$, Cole RB. Analysis of the volatile organic compounds in Cinnamomum cassia bark by direct sample introduction thermal desorption gas chromatography-mass spectrometry. J Essent Oil Res 2013; 25: 458-463.

7 Ishihara M, Tsuneya T. Components of the Agarwood Smoke on Heating. J Essent Oil Res 1993; 5: 419-423.

8 Miyoshi T, Ito M, Kitayama T, Isomori S, Yamashita F. Sedative Effects of Inhaled Benzylacetone and Structural Features Contributing to Its Activity. Biol Pharm Bull 2013; 36: 1474-1481.

9 Kajiya K, Inaki K, Tanaka M, Haga T, Kataoka H, Touhara K. Molecular Bases of Odor Discrimination: Reconstitution of Olfactory Receptors that Recognize Overlapping Sets of Odorants. J Neurosci 2001; 21: 6018-6025.

10 Tasaka T, Aoshima $H$. Effect of monoterpene alcohols on the expression of $\mathrm{GABA}_{\mathrm{A}}$ receptor subunits in the brain of mice. Aroma Res 2010; 11: 345-351.

11 Ito $K$, Ito $M$. The sedative effect of inhaled terpinolene in mice and its structureactivity relationships. J Nat Med 2013; 67: 833-837.

12 Ogawa K, Miyoshi T, Kitayama T, Ito M. Locomotor-Reducing Effects and Structural Characteristics of Inhaled Zerumbone and Tetrahydrozerumbone Derivatives. Biol 
Pharm Bull 2014; 37: 1559-1563.

13 Schwartz MW, Woods SC, Porte D. Jr, Seeley RJ, Baskin DG. Central nervous system control of food intake. Nature 2000; 404: 661-671.

14 Rahminiwati $M$, Nishimura $M$. Effects of $\Delta 9$-Tetrahydrocannabinol and Diazepam on Feeding Behavior in Mice. J Vet Med Sci 1999; 61: 351-355.

15 Jamshidi $N$, Taylor DA. Anandamide administration into the ventromedial hypothalamus stimulates appetite in rats. Br J Pharmacol 2001; 134: 1151-1154.

16 Majeed NH, Przewłocka B, Wedzony K, Przewłocki R. Stimulation of food intake following opioid microinjection into the nucleus accumbens septi in rats. Peptides 1986; 7: 711-716.

17 Akamizu T, Iwakura H, Ariyasu H, Hosoda H, Murayama T, Yokode M, Teramukai S, Seno H, Chiba T, Noma S, Nakai Y, Fukunaga M, Nakai Y, Kanagawa K, FD Clinical Study Team. Repeated administration of ghrelin to patients with functional dyspepsia: its effects on food intake and appetite. Eur J Endocrinol 2008; 158: 491-498.

18 Fujiwara $M$. Characteristics of abnormal behavior induced by $\Delta 9$-tetrahydrocannabinol in rats. Folia Pharmacologica Japonica 2001; 117: 35-41.

19 Habara K. Drug Abuse Prevention Strategy and National Crisis Management Policy. The Journal of Policy Studies 2008; 1: 95-111.

20 Nestler EJ. Historical review: Molecular and cellular mechanisms of opiate and cocaine addiction. TRENDS Pharmacol Sci 2004; 25: 210-218.

21 Rickels K, Case WG, Downing RW, Winokur A. Long-term diazepam therapy and clinical outcome. JAMA 1983; 250: 767-771.

22 Delhanty PJD, Huisman M, Julien M, Mouchain K, Brune P, Themmen APN, Abribat $T$, van der Lely AJ. The acylated (AG) to unacylated (UAG) ghrelin ratio in esterase inhibitor-treated blood is higher than previously described. Clinical Endocrinology 2014; 82: 142-146.

23 Takeda H, Sadakane C, Hattori T, Katsurada T, Ohkawara T, Nagai K, Asaka M. Rikkunshito, an Herbal Medicine, Suppresses Cisplatin-Induced Anorexia in Rats Via 5-HT2 Receptor Antagonism. Gastroenterology 2008; 134: 2004-2013.

24 Shintani M, Ogawa Y, Ebihara K, Aizawa-Abe M, Miyanaga F, Takaya K, Hayashi T, Inoue G, Hosoda K, Kojima M, Kangawa K, Nakao K. Ghrelin, an Endogenous Growth Hormone Secretagogue, Is a Novel Orexigenic Peptide That Antagonizes Leptin Action Through the Activation of Hypothalamic Neuropeptide Y/Y1 Receptor Pathway. Diabetes 2001; 50: 227-232.

25 Hur MH, Kim C, Kim CH, Ahn HC, Ahn HY. The Effects of Inhalation of Essential Oils on the Body Weight, Food Efficiency Rate and Serum Leptin of Growing SD Rats. 
J Korean Acad Nurs 2006; 36: 236-243.

26 Urabe A, Shimada K, Kawai S. Today’s Drug Therapy in 2015, Nankodo; 2015: 712. 27 Furudono Y, Sone Y, Takizawa K, Hirono J, Sato T. Relationship between Peripheral Receptor Code and Perceived Odor Quality. Chem Senses 2009; 34: 151-158.

28 Asakawa A, Inui A, Kaga T, Yuzuriha H, Nagata T, Ueno N, Makino S, Fujimiya M, Niijima A, Fujino MA, Kasuga M. Ghrelin Is an Appetite-Stimulatory Signal From Stomach With Structural Resemblance to Motilin. Gastroenterology 2001; 120: 337-345.

29 Shimizu H, Oh-I S, Hashimoto K, Nakata M, Yamamoto S, Yoshida N, Eguchi H, Kato I, Inoue K, Satoh T, Okada S, Yamada M, Yada T, Mori M. Peripheral Administration of Nesfatin-1 Reduces Food Intake in Mice: The Leptin-Independent Mechanism. Endocrinology 2009; 150: 662-671.

30 Schlesinger J, Tönjes M, Schueler M, Zhang Q, Dunkel I, Sperling SR. Evaluation of the LightCycler 1536 Instrument for high-throughput quantitative real-time PCR. Methods 2010; 50: 19-22.

31 Livak KJ, Schmittgen TD. Analysis of Relative Gene Expression Data Using Real-Time Quantitative PCR and the $2^{-\Delta \Delta C_{T}}$ Method. Methods 2001; 25: 402-408.

Figures and Tables<smiles>O=C/C=C/c1ccccc1</smiles><smiles>CC(=O)CCc1ccccc1</smiles><smiles>CCC(=O)Cc1ccccc1</smiles><smiles>CCCCc1ccccc1</smiles><smiles>CC(=O)CCC=C(C)C</smiles><smiles>O=Cc1ccccc1</smiles>

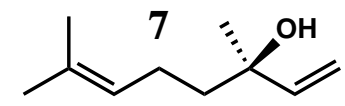

Fig. 1. Compounds tested in this study.

1. trans-Cinnamaldehyde, 2. benzylacetone, 3. 1-phenyl-2-butanone, 4. butylbenzene,

5. 6-methyl-5-hepten-2-one, 6. benzaldehyde, 7. (R)-linalool 


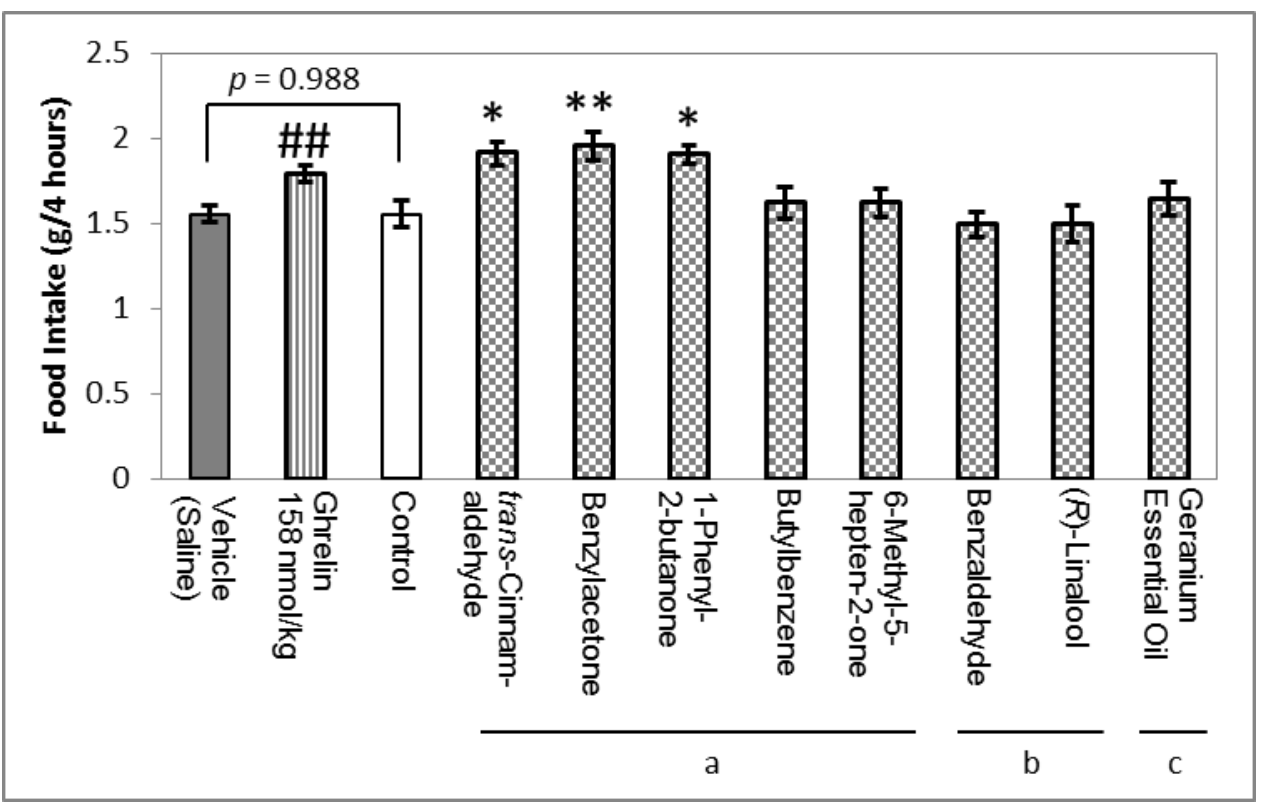

Fig. 2. Appetite enhancement in fasted mice by inhalation of fragrant compounds.

a: $4.5 \times 10^{-4} \mathrm{mg} /$ cage, b: $4.5 \times 10^{-5} \mathrm{mg} / \mathrm{cage}$, c: $4.5 \times 10^{-3} \mathrm{mg} /$ cage. Vehicle: saline injected i.p.; positive control: ghrelin; control: triethyl citrate inhalation. Data are expressed as mean \pm SEM ( $n=$ 8 mice). Statistical analysis was performed using subsequent $t$-test with Bonferroni correction for multiple comparisons and one-way analysis of variance (ANOVA) followed by Dunnett's test. ${ }^{*} p<$ 0.05 and ${ }^{* *} p<0.01$ vs. control group; \#\#p $<0.01$ vs. vehicle group.

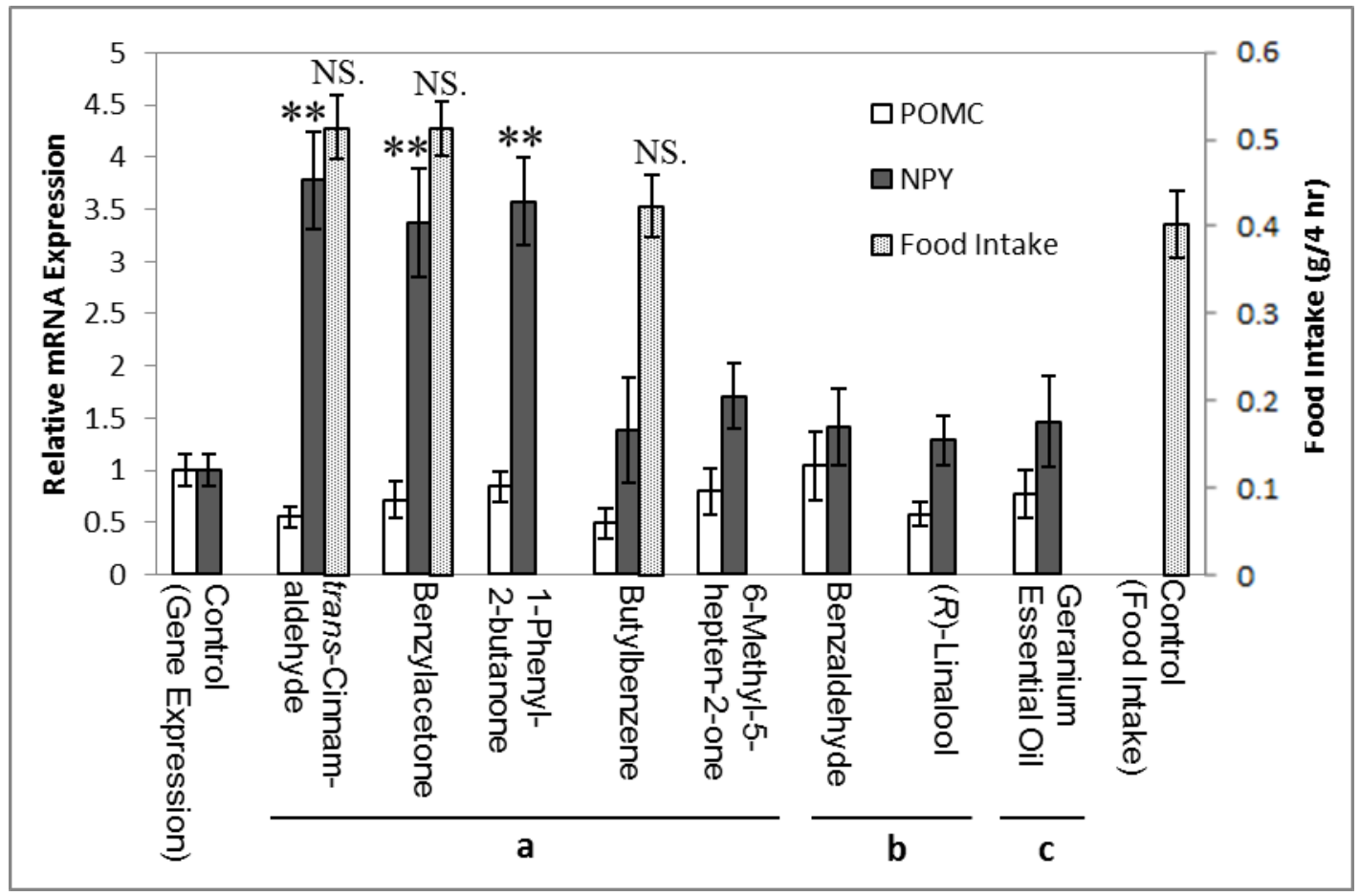

Fig. 3. Gene expression and appetite enhancement by inhalation of fragrant compounds 
in unfasted mice.

a: $4.5 \times 10^{-4} \mathrm{mg} / \mathrm{cage}$, b: $4.5 \times 10^{-5} \mathrm{mg} / \mathrm{cage}$, c: $4.5 \times 10^{-3} \mathrm{mg} / \mathrm{cage}$. Data are expressed as mean \pm SEM ( $\mathrm{n}=5$ mice). Statistical analysis was performed using one-way ANOVA followed by Dunnett's test. ${ }^{* *} p<0.01$ vs. control group.

\begin{tabular}{|c|c|c|c|c|c|}
\hline & Primer sequence & $\begin{array}{c}\text { Tm value } \\
\left({ }^{\circ} \mathrm{C}\right)\end{array}$ & Calibration curve & $\begin{array}{c}\text { PCR } \\
\text { efficiency }\end{array}$ & $\begin{array}{c}\text { Amplicon } \\
\text { size }\end{array}$ \\
\hline $\begin{array}{l}\beta \text {-actin } \\
\text { forward }\end{array}$ & 5'-CTAAGGCCAACCGTGAAAAG-3' & 48.0 & \multirow{2}{*}{$\begin{array}{c}\mathrm{y}=-3.868 \log (\mathrm{x})+35.516 \\
\left(\mathrm{R}^{2}=0.989\right)\end{array}$} & \multirow{2}{*}{0.814} & \multirow{2}{*}{104 bp } \\
\hline $\begin{array}{l}\beta \text {-actin } \\
\text { reverse }\end{array}$ & 5'-ACCAGAGGCATACAGGGACA-3' & 50.0 & & & \\
\hline $\begin{array}{l}\text { POMC } \\
\text { forward }\end{array}$ & 5’-CATTAGGCTTGGAGTAGGTC-3’' & 48.0 & \multirow{2}{*}{$\begin{array}{c}\mathrm{y}=-3.889 \log (\mathrm{x})+40.782 \\
\left(\mathrm{R}^{2}=0.997\right)\end{array}$} & \multirow{2}{*}{0.808} & \multirow{2}{*}{154 bp } \\
\hline $\begin{array}{l}\text { POMC } \\
\text { reverse }\end{array}$ & 5'-TCTTGACGATGGCGTTCTTG-3' & 48.0 & & & \\
\hline $\begin{array}{l}\text { NPY } \\
\text { forward }\end{array}$ & 5’-GTGTGTTTGGGCATTCTG-3’ & 44.2 & \multirow{2}{*}{$\begin{array}{c}y=-3.815 \log (x)+34.732 \\
\left(R^{2}=0.998\right)\end{array}$} & \multirow{2}{*}{0.829} & \multirow{2}{*}{112 bp } \\
\hline $\begin{array}{l}\text { NPY } \\
\text { reverse }\end{array}$ & 5’-TTGATGTAGTGTCGCAGAGC-3’ & 48.0 & & & \\
\hline
\end{tabular}

Table 1. Characteristics of primers and their amplicons.

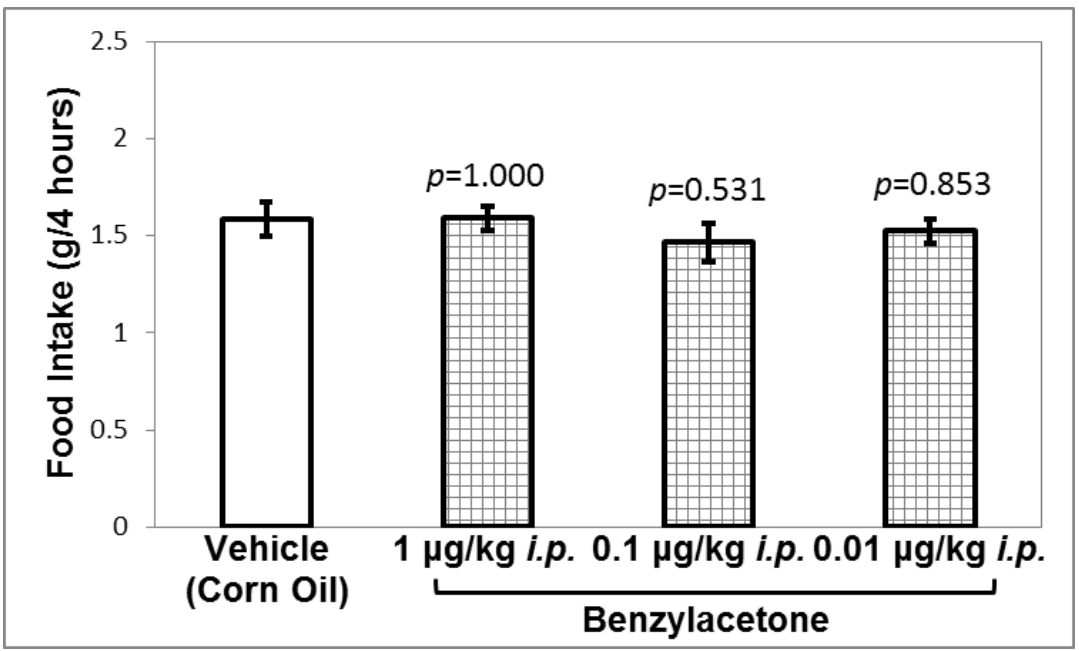

Fig. 4. Appetite-enhancing effects of benzylacetone administered via intraperitoneal injection in fasted mice.

Data are expressed as mean \pm SEM ( $n=8$ mice). Statistical analysis was performed using subsequent $t$-test with Bonferroni correction for multiple comparisons and one-way ANOVA followed by Dunnett's test. 